\title{
Retail Gentrification in Residential Neighborhoods: Gyeongridan, Seoul
}

\author{
Yeonju Jeong, Jayun Heo, Changmu Jung \\ Department of Civil and Environmental Engineering, \\ Seoul National University \\ owlishbehaviour@gmail.com
}

\begin{abstract}
This paper is an examination of the gentrification process and its impact on local businesses in the Gyeongridan neighborhood, Seoul. Commercial gentrification has many benefits as well as being associated with local disparity of residents. While culturally sensitive visitors enjoy the new consumption experience, it is at the expense of the local businesses. In-depth interviews were conducted with longterm shop owners to investigate the impact of gentrification in their businesses and lives. Our interpretive examination of different attitudes towards the transition revealed that reactions of long-term shop owners vary according to their situation, somewhat contrary to previous studies.
\end{abstract}

Keywords: retail gentrification; sustainable neighborhood; Gyeongridan; displacement

eISSN 2398-4295 @ 2018. The Authors. Published for AMER ABRA cE-Bs by e-International Publishing House, Ltd., UK. This is an open-access article under the CC BY-NC-ND license (http://creativecommons.org/licenses/bync-nd/4.0/). Peer-review under responsibility of AMER (Association of Malaysian Environment-Behaviour Researchers), ABRA (Association of Behavioural Researchers on Asians) and cE-Bs (Centre for EnvironmentBehaviour Studies), Faculty of Architecture, Planning \& Surveying, Universiti Teknologi MARA, Malaysia.

DOI: http://dx.doi.org/10.21834/ajbes.v3i12.129 


\subsection{Introduction}

During the recent years Seoul has seen a few neighbourhoods rising as new commercial centers. Formerly considered as residential areas, these emerging districts have in common trendy restaurants and cafes. A phenomenon at the focal point of these new areas is the current trend of people searching for a quality and unique dining experience, establishing itself as an urban ritual. This adventure involves spending a weekend afternoon lining up in front of a popular café for a latte on the terrace.

What distinguishes these areas from the old urban centers is that they offer a type of vibe and products that few other urban areas do. This draws praise from the media and state for diversifying cultural and social experience available in the city and for 'revitalizing' the inner city. Indeed, the majority of new retail businesses reflect the diversified needs of the young and cultured.

Our attention, however, is not solely on the positive aspects in such consumption spaces. In these emerging neighborhoods, there seems to be a tangible divide between the new and old retail businesses that is greatly neglected in the discourse of . In search of an answer, the remainder of this paper explores recent academic works on retail gentrification that resonate with what is happening in the Gyeongridan neighborhood, dubbed by media as "the hot place." Along with statistical and photographic evidence of the ongoing retail gentrification process in Gyeongridan neighborhood of Seoul, the main points of our arguments will be based on our findings from interviews with the long-term residents of our field site.

\subsection{Literature Review}

\subsection{Commercial concentration as a gentrification process}

Until recently, the majority of the gentrification literature had a tendency to focus on the housing sector. However, this has shifted with a number of scholars from different fields paying attention to the retail sector (Ernst and Doucet 2013). This shift is critical as the retail sector not only provides essential services and goods to the community but is also a 'frontier' of further gentrification (Gonzalez and Wiley 2013).

Gonzalez and Wiley, in their study on a traditional market in Leeds (2013), argue that a retail market in the central part of a city tends to undergo a renewal after a period of disinvestment, with or without public intervention, and turns out to be a gentrified upscale market that does not fit its old clientele anymore.

According to preceding studies, retail gentrification goes through two different stages. First, 'pioneers' settle in a disinvested neighborhood by opening independently-owned businesses taking advantage of relatively low rents and the central location (Smith 1996). Often with the aid of social media, this new retail formation attracts young and relatively affluent customers, bringing a new kind of vitality to the neighborhood. Second, new boutiques mark a promising spot for investment, inviting corporate capital in turn. When its reputation as a new urban center builds attracting customers from other parts of the city, chain stores start to appear. 


\subsection{Impact of retail establishments on social inclusion}

Many studies address positive effects of retail developments offering spaces for cultural and social practices. In those studies, such new commercial landscape is the result of a development of big shopping outlet (Hanan 2012), promotion of commercial establishments near a cultural heritage site (Sulaiman and Shamsuddina 2012) and a quasi-private development project (Nasution and Zahrah 2004). Ujang (2010) notes that a place attachment is linked with the identity of a commercial street. A meticulous research on different aesthetic elements at restaurants shows commercial environments can play a positive role in promoting socially vibrant atmosphere (Astuti and Hanan 2010).

However, according to Zukin (2009) the positive social effect of emerging retail establishments is limited, as stores in gentrifying neighborhoods tend to cater only to those who desire a distinctive symbolic status. The retail establishments that seem to foster social and cultural vitality, in her view, are responsible for socio-economic polarization. 'Authenticity' is mentioned as a value that is sought for among the new retail owners and customers. New restaurants, bars and cafes in gentrifying neighborhoods feature well-designed furniture, indie music, exotic dishes and idiosyncratic signage. These new shops strike a chord with a certain group of people who differentiate themselves by purchasing unique and 'authentic' goods. However, according to Zukin, this 'fabricated' authenticity pushes out working-class and minorities who are not part of that subculture.

Some retail gentrification studies argue that gentrification creates a racial and class boundary. Findings from interviews with black and white residents of a gentrifying neighborhood in Portalnd (Sullivan and Shaw 2011) reveal negative feelings among black residents and their sense of exclusion. By interviewing non-gentrifiers in a gentrifying neighborhood in Amsterdam, Ernst and Doucet (2013) reveals that the gentrification process is welcomed among the Dutch residents because of the influx of non-immigrant population.

Alongside studies on the gentrification-induced racial and symbolic divide, Slater(2006) warns of a recent trend in gentrification research that 'evicts' critical perspectives in the issue, possibly due to ideological differences, a disinterest of displacement as a gentrification question and the neoliberalism influence in the academia.

Based on our reviews of this retail gentrification literature, the ongoing commercial intensification in some neighborhoods of Seoul can be understood as going through gentrification. The attitudes towards the trend can vary depending on the extent of gentrification and demographic makeup of the area, however the gentrification-induced change does have negative consequences.

While there have been studies based on interviews with residents, very few of them focus on the people who fall victim from the earliest stage: the long-term shop owners. Therefore, to investigate the impact of retail intensification on local businesses, this paper focuses on long-term business owners.

\subsection{Methodology}

Our field site is the Gyeongridan neighborhood of Seoul. To examine the impact on local business, we contacted the representative of a local business association and met other 
business owners afterwards. In total over 50 shop owners were interviewed including the ones who participated in our survey. The profile of the interviewee and respondents were predominantly non-gentrifiers who had either lived or run businesses in the neighborhood for many years; many of them were born and raised in the area. All our respondents were Koreans; $40 \%$ were female and the rest were male. Some of them are tenants and some run their business in buildings that they own. All interviews were conducted in Korean and the quoted part was translated into English by the authors. Conversation with some interviewees who refused to be recorded were reconstructed based on our notes. To respect their anonymity, we refer to all of our interview subjects, stores, and community organizations by general descriptors.
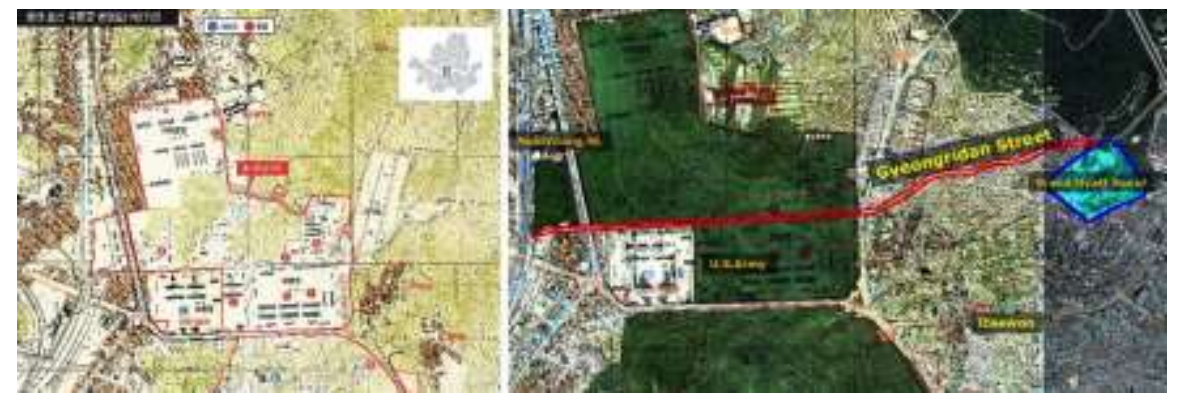

Figure 1: Formation of Gyeongridan Street (a) 1927 Map; (b) Overlay with 2014 Map (Source : the Hangyoreh, 2013-05-16 http://www.hani.co.kr)

\subsection{The Changing Retail Landscape}

Gyeongridan sits next to Itaewon, an urban center that underwent a major gentrification recently. Once neglected and rather isolated being surrounded by the Namsan Mountain and a US army camp, it is one of the few old neighborhoods whose population is predominantly natives and long-term residents, having survived a series of urban renewal projects that have transformed a substantial portion of the city.

Most of the new shops are dotted along the main street, called Gyeongridan Street, which was originally made for agricultural use and was subsequently paved when Grand Hyatt Seoul opened in 1978. Being only three meters wide, it sits on a mountain and is thus not ideal for walking with little space for parking.

The area is zoned Class 2 General Residential (typically in the inner blocks near narrow roads) and due to its proximity to the mountain it has a height limitation of 16 meters. The Decree of Building Act prohibits large commercial buildings in General Residential areas, but housing units can be converted to small retail establishments and offices. 


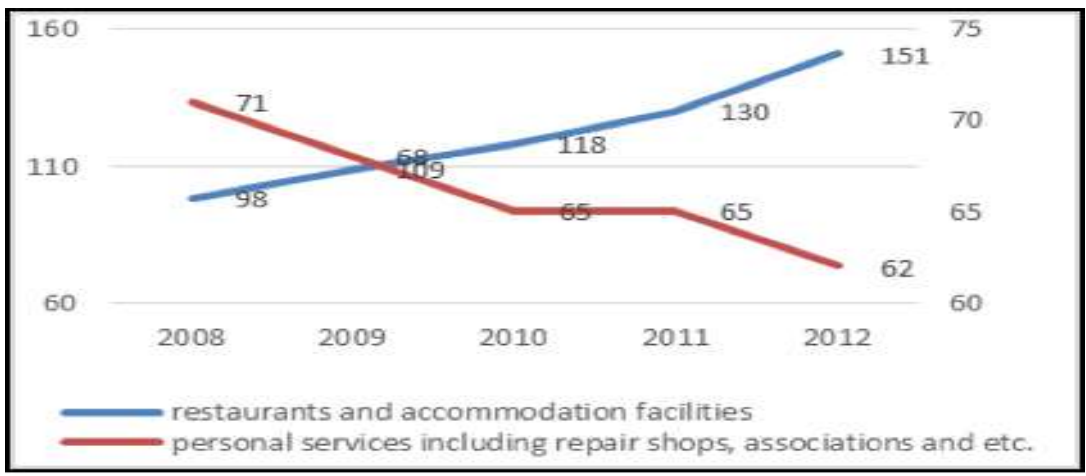

Figure 2: Trend in the Share of Restaurants and Personal Services (Source Seoul Statistics (http://stat.seoul.go.kr)

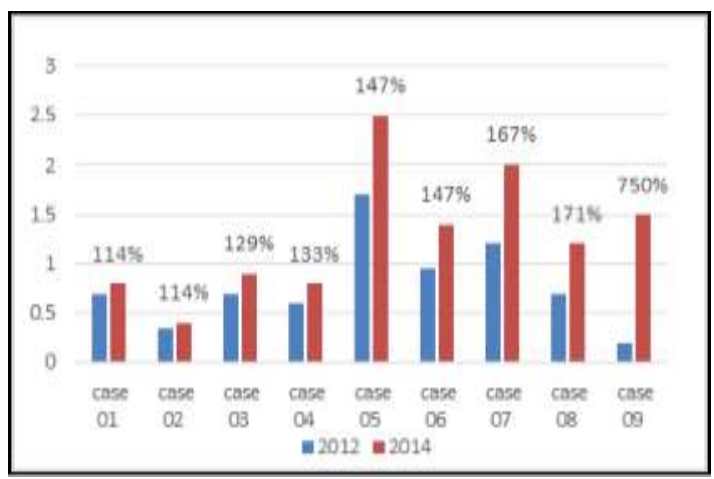

Figure 3: Rent Increase Rates 2012-2014

Source: survey conducted by the authors)

\section{Changing retail dynamics of Gyeongridan}

At present, gentrification in our field site is in an early stage. However, our statistical findings show some critical shift. Figure 2 and 3 shows a rapid increase in the number of food and beverage establishments between 2008 and 2012 and a decline in personal service industry such as home repair.

To obtain rent data, we conducted a survey among 50 members of a business owners' association of Gyeongridan, whose members are predominantly long-term residents. Due to the sensitive nature of the information, out of 50 requests, we only collected 30 responses. The physical change in the retail landscape of Gyeongridan is depicted vividly in Figure 4. The building that housed local businesses such as a pet house, a delivery restaurant and a small diner has become occupied by trendy restaurants. 


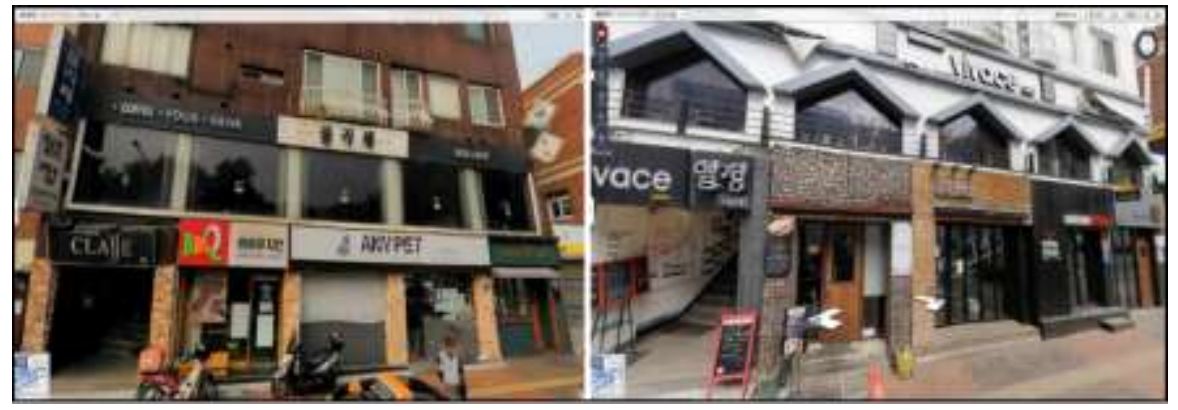

Figure 4: Changing Retail Landscape of Gyeongridan (a) October 2010 (b) April 2013 (Source: Naver Street View)z

\subsection{Impact on Long-Term Businesses}

\subsection{The distressed}

When asked how they feel about the gentrification-induced neighborhood change, many expressed their resentment towards the rising rent. One respondent has moved multiple times within the neighborhood due to the rising rents on the main street. This type of involuntary relocation is typical of gentrifying neighborhoods in Seoul. Despite the move to a less accessible area, some of them manage to continue their business as their job deals with longtime local patrons. Hair salons, for example, fall into this category.

However, rising rents generally result in forced abandoning of home business; increasingly expensive rent as well as the general feeling of despair seems to be responsible. A drycleaner owner and a tenant who has to move as she could not afford the rent increase decided to have a career change. "My clientele are all here. I thought about moving to a different city but I will quit... I might apply for a caretaker's license." Besides involuntary career change, the ongoing gentrification also pushed forward the retirement of some senior business owners. Another interviewee described his plan to go out of business after a few years, due to his old age:

"Before this (hardware shop), I had a stationary store. That didn't last because it wasn't lucrative. Now it seems this isn't either. I can't afford the twice the rent I used to pay with this deteriorating business. I think it's time I retired. Not sure if I would survive even if I wanted to." [Male, hardware shop owner]

Some expressed discomfort with the changing atmosphere of the neighborhood. A woman who displayed her nostalgia for the old vibe of Gyeongridan expresses her distress:

"When I first visited here in the 80's I really liked the way it felt like an old country village so I started my shop though I was and still live in other neighborhood. Now the things changed and it doesn't feel 
the same. Seems like this town is becoming the second Itaewon and my old clients have left. It's not a cozy small village as it used to be." [Female, cosmetic shop owner]

Some criticized the lack of diversity in the services that the new shops they offer. They compared the new shops to those in Itaewon in terms of scale and contents. This may be the reason behind their skepticism toward the new retail establishments.

"They are just a bunch of coffee shops and restaurants. It's all about eating and drinking. There's nothing else. You can't even park here. In Itaewon there are big nightclubs and pubs full of people from the world. That we don't have here. I doubt this (gentrification) will last." [Male, a karaoke owner]

In sum, our respondents linked their distress with how the neighborhood is changing to different reasons; some are forced to leave or retire, while others were nostalgic about the neighborhood's old charm or expressed dissatisfaction with the new shops. However, consistent in our interviewee's responses was that they do not relate to the new atmosphere. There was no mention of cultural and social aspects of the gentrification, unlike previous studies (Sullivan and Shaw 2011; Ernst and Coucet 2013) that come across positive responses. This confirms the presence of certain division between the new and old shop owners as pointed out by Zukin (2009) and Slater (2006).

\subsection{The accepting}

Some are more impervious to the change than others; the building owners were welcoming of the gentrification. For them, sale of their newly appreciated property is an option; it is a way of gaining economic fortune. One building owner, for example, said that "people should be aware of the changes in their environment and act accordingly." Having been approached by big conglomerates about selling his property for a large sum of money, he decided to leave the place where he was born and raised.

"I have lived here all my life trying out different things. I once ran a restaurant, then a karaoke and a real estate agency too. People (long-term business owners) here they just stick to one thing for all their lives and don't know what to do outside this little town. I tell them to find their way out of this." [Male, a building owner]

Some of the property owners plan to scrap their business and have their children take over their property for lease business or a different one more in tune with the young customers. This is not a surprise since in Korea where most children inherit their parents' properties when they retire in exchange of providing care.

The increased number of visitors brings does benefit some of the old businesses. $A$ woman who runs a small Korean-style pub appreciates the transition.

"They come here for a fancy cocktail or an Italian dinner but when they get drunk I know where they end up. It's where they can drink and eat food they feel most comfortable with. I work until late hours these days because the young people come in at late hours. In the early evening I have my old patrons." [Female, Korean pub owner] 
While the anticipation of making a profit with their property or increased customers was prevalent, few seemed to appreciate or be interested in the distinguished characteristics of new retail. When asked whether they would opt for a younger business, our interviewees did not show such intention.

\subsection{The ambivalent}

Somewhat contrary to our expectation, many business owners were either ambivalent about, or were rather complying with the transition. Professionals such as an optician and a veterinarian fall into this group. A veterinarian is "staying nonetheless" because his job can afford higher rent, adding that the rents before were "actually too cheap" considering the potential of the area. A middle-aged woman who was asked for a rent increase says she understands "the capitalist system" and plans to move her business. "I can do this elsewhere. I will just find some other small neighborhood that is cheaper."

Unlike the descriptions in previous studies, the tension between the landlord and tenants is not very stark. In fact, some of the tenants manage to avoid the recent years' heavy increase in rents. "My brother (landlord) is not that kind of person who kicks out old friends... We are family," says a restaurant owner who refuses to reveal his current rent. The strong tie among the community members in Gyeongridan might be responsible for this understanding. This surprisingly applies to the ones who are forced to leave, with some stating that they were "paying far less than the newcomers."

"I don't think all the landlords are bad. They have kids to grow. If they can make more money, who wouldn't? I would do the same thing. I can't help but accept what they ask until my situation allows it. Hopefully my sales will increase." [Male, grocery store owner]

When asked what they think is the reason is behind the new stores' success, the responses were mixed with confusion and envy. Some seemed to be fascinated by the entrepreneurship of the young shop owners, but looked hesitant when asked if they want to start a trendier business, stating:

"I am too old and I have kids. It is too risky for me to get into it."

"I don't understand how people (customers) find their way to this small town for those new cafes. You have to climb up the hill to get to some places. This town didn't have many people from outside. But I started to see young fellows and they are lining up in front of waffle shops and bars." [Male, rice shop owner]

Among those who showed neither enthusiasm nor resentment, there is a sentiment of passive acceptance, seeing the market force as "something undefeatable." Some seem to appreciate their lessor for not raising the rent like many others. Surprisingly, some evictees showed generous attitudes toward their lessor's decision. This may be due to social cohesion among the Gyeongridan community. 


\section{Conclusions}

This paper challenges the popular notion of the retail gentrification and its impact on local businesses. While widely celebrated, retail gentrification can lead to deleterious consequences as warned by the literature reviewed. Our findings show the gentrification in Gyeongridan has overall been against the benefits of the old businesses.

By interviewing long-term shop owners, we uncovered discourses, which are welcoming to, accepting of, and frustrated with the process. The resentment was due to rent hikes, the dismantling community, and their dissatisfaction with new stores. Although a few of them did gain unforeseen profits from the increased visitors and property values, the impact is limited.

Yet the dynamic in the changing local retail landscape turned out to be more complex than expected. Despite the displacement caused by the rent hikes and neighborhood change, the indignation among some of the evictees was not as salient as is depicted in the reviewed literature. Factors such as property ownership and professional skill ownership seem to influence the perception of gentrification, including the strong kinship of this old community.

This paper highlights the overlooked reality of retail intensification in long-blighted residential neighborhoods, especially the case of old business. The emerging neighborhoods in Seoul today, including our field site, is still at its early phases of retail gentrification. The distress is neither the result of state intervention nor the major corporates' business practice; community actions are unlikely to take place, making the situation invisible.

Discourses on retail gentrification and its impact on long-term businesses are not reducible to the diversification or sophistication of consumption culture, since is a worldwide phenomenon that causes exclusion and further gentrification. Should profits determine the type of businesses to be established in a neighborhood? We contend that the right to live and work should be emphasized before the right to consume.

\section{References}

Ernst, O., \& Doucet, B. (2014). A Window on the (Changing) Neighbourhood: The Role of Pubs in the Contested Spaces of Gentrification. Tijdschrift voor economische en sociale geografie, 105(2), 189-205.

Gonzalez, S., \& Waley, P. (2013). Traditional Retail Markets: The New Gentrification Frontier?. Antipode, 45(4), 965-983.

Hanan, H. (2012). Pedestrian Ways, Informalities and Urban Spectacles. Procedia-Social and Behavioral Sciences, $36,421-430$.

Ja'afar, N. H., Sulaiman, A. B., \& Shamsuddin, S. (2012). The contribution of landscape features on traditional streets in Malaysia. Procedia-Social and Behavioral Sciences, 50, 643-656.

Nasution, A. D., \& Zahrah, W. (2012). Public Open Space's Contribution to Quality of Life: Does privatisation matters?.

Slater, T. (2006). The eviction of critical perspectives from gentrification research. International Journal of Urban and Regional Research, 30(4), 737-757. 
Jeong, Y., et.al. / Asian Journal of Behavioural Studies (AjBeS), 3(12) Jul / Aug 2018 (p. 125-134)

Smith, N. (2006). Gentrification generalized: from local anomaly to urban 'regeneration'as global urban strategy. Frontiers of capital: ethnographic reflections on the new economy, 191-208.

Sullivan, D. M., \& Shaw, S. C. (2011). Retail gentrification and race: The case of Alberta Street in Portland, Oregon. Urban Affairs Review, 47(3), 413-432.

Zukin, S., Trujillo, V., Frase, P., Jackson, D., Recuber, T., \& Walker, A. (2009). New retail capital and neighborhood change: boutiques and gentrification in New York City. City \& Community, 8(1), 47-64. 